\title{
The state of wooden housing architecture preservation from the interwar period in cities of the Lublin region. Protection possibilities
}

\author{
Ewa Netczuk-Pol \\ https://orcid.org/0000-0002-2514-8314 \\ ewa.mafalda@netczuk.org
}

Zakład Konstrukcji i Budownictwa Ogólnego, Wydział Architektury, Politechnika Wroctawska

\begin{abstract}
Summary: The article describes the condition of the wooden buildings created in the interwar period in the Lublin region and the method of its conservation, taking into account legal forms in force in Poland and in the world. This is a very substantial topic, because buildings of this type are increasingly disappearing from the landscape of a small city, in favor of catalog construction, thereby destroying the unique small-town landscape.
\end{abstract}

Keywords: Lublin region, wooden buildings, interwar period, condition, forms of legal protection.

\section{Introduction}

Interwar period in Poland was a time of rapid state reconstruction, not only at political level, but also in architecture. It must be stresses, that war loses incurred in the area of built environment were enormous. Thus, prevailing housing crisis was substantial, therefore the State decided to help citizens in the reconstruction ${ }^{1}$. At the beginning of the 1920s, the first housing associations began their operation and the major of which established in 1934 - was Towarzystwo Osiedli Robotniczych (Eng. Society of Workers' Housing Estates - self translation). The aim of aforementioned organization was raising housing estates for a less prosperous part of society. First of all, small single-family houses were built ${ }^{2}$, most often in a terraced manner and blocks of flats. The newly designed households were located mostly in suburbs or on vacant plots.

Wooden buildings in the Lublin region at that time were very popular, due to several factors. Not only wood was an easily available material, but areas spoken of had rich tradition related to timber construction. Hence, above all, it was simple and economic to use this technology instead of other possibilities.

The starting research material used in this study for determining wooden buildings preservation condition, were projects retained in the State Archives and Karty Ewidencji Zabytków Architektury i Budownictwa (Architecture and Building Monuments Record Cards) so-called white cards (polish biate karty). Records analyzed allowed defining the date of each object creation. However, it must be highlighted, that there is no certainty for implementation of retained house projects in showed a form. Some of the buildings, may have had not occurred at all. In addition, it should be noted, that at the beginning of operation of the Polish state, the building regulations of the partitioning powers were in force, including the former Kingdom of Poland until 1928,

1 In the Lublin Voivodeship, according to data from the 1926 census, there were an average of 4.7 people per apartment in the city. Maty Rocznik Statystyczny, no. 4, 1933.

2 An example would be the Legionistów estate in Lublin, where single-family houses of mixed wood and brick construction have survived. 
in which no design documentation was required. This raises some issues in determining the actual date when objects were created. To carry out a reliable analysis, there were selected houses, which had sufficient archival documentation.

For research there were selected cities that in the discussed period had formal city status or regained their city rights at that time, i.e. from the northern part of the region (Biała Podlaska, Janów Podlaski, Łuków, Międzyrzec Podlaski), central (Kock, Lubartów, Lublin, Ostrów Lubelski, Parczew, Puławy) and southern (Chełm, Dubienka, Hrubieszów, Krasnystaw, Tomaszów Lubelski, Zamość) as well as two small town settlements: Bełżyce, Izbica and one health resort - Nałęczów.

\section{Wooden buildings of the interwar period - form}

In the first years after the war, both the partitioning powers and the former Polish Kingdom building regulations were simultaneously still in force ${ }^{3}$ until 1928 , when a standardized building code was adopted ${ }^{4}$. The new law limited the height of timber or mixed wooden-brick buildings, erected in urban areas to four fathoms, i.e. $8.52 \mathrm{~m}$ (this distance was measured from the ground level to the eaves). Moreover, non-fireproof buildings longer than 25 meters had to be separated by a fire wall every aforementioned 25 meters $^{5}$. The roofs of the buildings had to be covered with flameproof material.

Concerning a style of elaborated buildings, in interwar period, several catalogs were created containing typical single-family wooden houses, however none of them was adopted in this area. Local building tradition was in advance at all times, despite proposed patterns or weak influence of a few model projects, especially those erected in national style. Noticeable are also rare examples of using the same project repeatedly within one city. In the Lublin region popularity gained a style referring to the traditional house construction, while so called manor style, understood in the classical sense, spread in the north. At the end of 1930s, functionalism became popular, especially in larger cities of elaborated region Focusing on structure details, most of timber buildings were raised in post-and-plank construction, sometimes with the use of log cabin. This frame structure was mainly implemented in porch structure, outbuildings and elements of small architecture. While, mixed construction houses, where ground floor was made of stone and wooden upper floor, were rather rare. Building facades, depending on the style and the region, were plastered or boarded. Roofs were most often manufactured as: gable, jerkin head (so called half-hip), stepped, dutch gable jerkin head dutch gable roof (in the southern region).

\section{State of the preservation}

Not many wooden or mixed-type residential buildings have survived to present day, and their current technical condition is often poor. In this case, comparing design documentation of particular home with its current state is often difficult, sometimes impossible. Reasons for poor condition can be seen in war damages brought by the World War II and the occupier's policy related to mass deportations. Abandoned houses, due to lack of proper maintenance, fell into ruins and were subjected to the process of destruction, leading to their complete disintegration (Fig. 1A). In addition, most of the nowadays inhabitants of these houses are mostly elderly, destitute people. Some of elaborated buildings are also owned by the city or municipality - among others serving as social low standard flats. Another reason for this condition is poor quality of original construction. Wooden buildings of period discussed were a response to prevailing housing crisis, some of them supposed to be temporary. Frequently their original function was changed throughout time and currently are adapted to the new way of use, i.e. for shops (Fig. 1B).

3 Dz.U. 1919 nr. 14 poz. 176, Dekret w przedmiocie tymczasowych przepisów budowlanych na obszarach byłego zaboru rosyjskiego compare Ustawy i rozporzadzenia z dziedziny budownictwa obowiazujace w Państwie Polskiem: ustawy i rozporzadzenia wydane przez władze polskie do dnia 1 czerwca 1923 r. obowiązujące bądź na obszarze całego państwa, bądź w poszczególnych dzielnicach oraz przepisy wydane przez b. władze rosyjskie i okupacyjne niemieckie, obowiązujące na obszarze b. zaboru rosyjskiego, ed. by Gustaw Szymkiewicz, Warszawa 1923.

4 Ustawa Budowlana. O prawie budowlanym i zabudowaniu osiedli z dnia 16 lutego 1928 roku, Warszawa 1928.

5 Ustawy i rozporządzenia..., op.cit., C. I, art. 200-201, compare Ustawa Budowlana..., op. cit., art. 202. 
Moreover, wooden houses were often rebuilt and their transformations were carried out without any conservation manner, so in this processes initial form was often destroyed. Window frames were replaced in many cases, in a way, where original casement windows have been changed for standard plastic ones. New typical joinery usually neither retained original size of window nor initial glass division, and thus openings lost their historical form. The same statement is true for roofing and in place of the historical coverage, cheap corrugated sheets were introduced. However, the most destructive procedure was thermal modernization of the buildings. Though, the process is required in order to update buildings to contemporary energy-saving requirements, at many occasions it was performed improperly and destroyed not only the detail, but also the entire structure of the building, by changing its historical form (Fig. 1C). The second negative factor was improper reconstruction. It was connected to a fact, that at erection time most of the houses did not have any media, and sanitary facilities inside the building were rare. In this cases, owners wanting to adapt homes to new living conditions, usually created additions. These were often made from modern materials, which resulted in changing original shapes of homes and disfiguring buildings original form (Fig. 1D). In addition, constant improper maintenance of wooden elements or complete absence of conservation activities lead to the destruction of building material, including unique details, such as: decorative corners (polish kożuchowanie), porches or ornamental window headers and aprons.

The enrichment of society is another factor in the disappearance of wooden buildings, often due to poor technical condition and too high cost of reconstruction. In respect of these facts, many timber structures are being demolished, in order to provide a place for new brick households. Highly rare positive practice, which was noted in this manner is translocation of the building, consisting of unfolding the whole structure and reassembling it in a new place. It was also observed that, formerly such activities took place, now they are gaining its supporters again. Another reason for reducing the number of wooden houses is their location. Previously situated on plots at the outskirts of cities, now these buildings are located in a downtown area, at sites attractive for new investments, like multifamily estates or commercial enterprises.
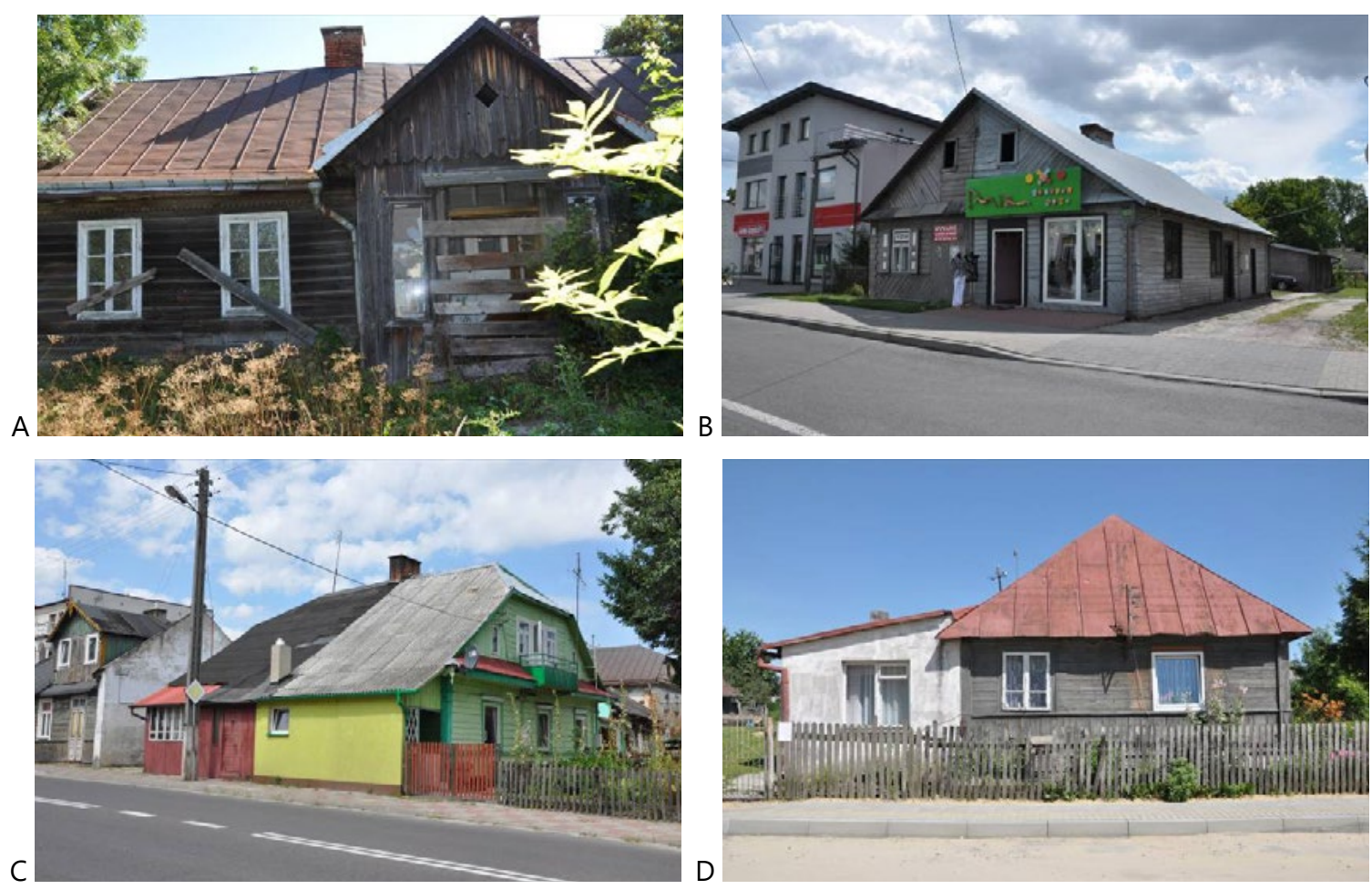

Fig. 1. A - Krasnystaw, Krakowskie przedmieście, B - Parczew, ul. Kościelna 42, C - Hrubieszów ul. 1 maja, D - Kock, ul. Ostrowskiego. Photo author 2012. 
In spite of many negative factors, which are affecting this buildings' development also positive examples have been noticed, in which owners with care are looking after their households, keeping its original form and the detail. Single objects are bought or offered to became part of open air museums or antique building museums, and thus are subject to proper conservation after which can serve as exhibits. One example is the Museum of the Lublin Village in Lublin, where currently a project is being carried out, aiming at reconstruction of a typical provincial town of Central Europe from the 1930s. On the exhibition area, there are not only residential wooden buildings, but also public edifices. This display, due to attention to detail, allows to present the character of a small town of the interwar period.

Unfortunately, despite the positive examples, the current condition of wooden architecture is poor. This is indicated by, among others statistical data from the 1980s presented by lgnacy Tłoczek, showing the percentage share of wooden houses in the Lublin region, in relation to the whole building number, which at that time was between 75 and $90 \%$. An example of a city, for which a plan was made in 1928 showing the type of buildings, was Łuków (fig. 2). In that plan about $70 \%$ of existing buildings, was timber structures, located outside the city center.



Fig. 2. Plan of the city of Łuków from 1928. Ed. author based on J.S. Majewski, Łuków, district town in the Lubelskie voivodship, Łuków 1930 , p. 47

Quantitative changes in wooden housing structure are large. To illustrate this process, author analyzed available archival materials and unpublished papers, for one representative city - Międzyrzec Podlaski, among others analyzed data as listed:

- The Measure Plan from $1942^{6}$, 
regional literature, mainly the Rocznik Międzyrzecki ${ }^{7}$,

- BEng Thesis of Tomasz Siedlanowski, Drewniana zabudowa mieszkalna Międzyrzeca Podlaskiego (Wooden residential buildings of Międzyrzec Podlaski), conducted under the supervision of assoc. prof. Eng. Arch. Elżbieta Przesmycka made at the Faculty of Civil and Sanitary Engineering of the Lublin University of Technology, defended in 2006,

- master's thesis of Łukasz Netczuk, Międzyrzc Podlaski - miejsca ożywione (Międzyrzec Podlaski - vivified places) conducted under the supervision of PhD. Eng. arch. Regina Maga-Jagielnicka made at the Faculty of Architecture of the Wrocław University of Technology defended in 2009.

The Measure Plan from 1942 refers to the Jewish quarter and lists wooden and brick buildings according to the state before the destruction. The Rocznik Międzyrzecki (yearbook) provides detailed data on the nature of buildings and their transformations. T. Siedlanowski's BEng Thesis attempts to register and valorize the condition of wooden buildings throughout the city, with a detailed inventory of several, selected objects. As the author writes on pages 5 and 48 of his work, it covered the scope of the detailed inventory only for a very small part of wooden houses ( 5 buildings, including 3 from the city and 2 from Rzeczyca) on the background of the general analysis of its condition presented on the map on page 47. It must be stressed, that detailed local vision of the city introduced for presented study, revealed, that there was much greater number of wooden buildings, literally 300 existing buildings and 49 from the Siedlanowski map non-existent in 2019, than the map of the analysis of the state of preservation in 2005 - 186 existing buildings (not including 2 objects from Rzeczyca, which was included in the work of Tomasz Siedlanowski, however this area is not formally part of the city and thus, was not included in presented author's research). Recalled map does not include many evidently wooden houses built before 1950, preserved until today in whole or in part, especially those that have been: plastered, subjected to thermal modernization or have had blurred traces of original wooden structure, as an effect of the reconstruction and renovation. In these buildings only the endings of ceiling beams, gable eaves board or wooden gables, reveal their original wooden structure. The largest deficiencies were recorded in the Stołpno and Zawadki housing estates and along Piłsudski and Zarówie Streets. Non less important is the record of the state of buildings at the beginning of the $21^{\text {st }}$ century, it also documents the inventory of several houses. Their author also does not rule out omission of other timber residential buildings, which identification is currently not possible, on the basis of external examination. However, in publication every effort was made to ensure, that the quantitative diagnosis of this type of buildings was as complete as possible. By the way, the technical state of reference was updated in relation to Siedlanowski's analysis of 2005, showing that 49 wooden house of this map do no longer exist.

Urban planning Master's Thesis of $Ł$. Netczuk, in addition to detailed urban and planning analyzes on the spatial development background of the city, in the form of maps presents the valorisation of preserved wooden residential architecture of Międzyrzec Podlaski. At page 49 author indicates that presented research have been conducted in the categories of cultural heritage, as the ones, that are very legible in the city landscape. In the analysis of cultural heritage in point 8 and 9 on aforementioned page, among the buildings appointed to be included in homogenous conservation protection, author lists two locally sanctioned customary categories of wooden housing: richer in spatial form and dimensions, the so-called burgher houses and manor houses (item 8.), supplemented by other smaller timber households of various forms (item 9.), listing the more valuable to preserve. The postulate of protection includes, in the form of a list (table 6), well-preserved wooden objects with a relatively well-documented history known at that time to the author (2008-2009), including buildings at Piłsudskiego from Sienkiewicza streets to the Piszczanka river - as the most aggregated and representative complex of buildings of this type in the city - and additionally 12 preserved wooden objects from point 8 and 9. - with valuable architecture and relatively good condition (page 49, full-scale drawing no. 5). The work also postulates the protection of this form of development by creating a tourist trail called: Program of attractions and cultural heritage of the Międzyrzec Region (pp. 4, 66-67, 98, full-scale drawing no. 1) as well as conservation and cultural protection zones in spatial development plans (p. 61, 70, 73, full-scale drawing no. 3). 


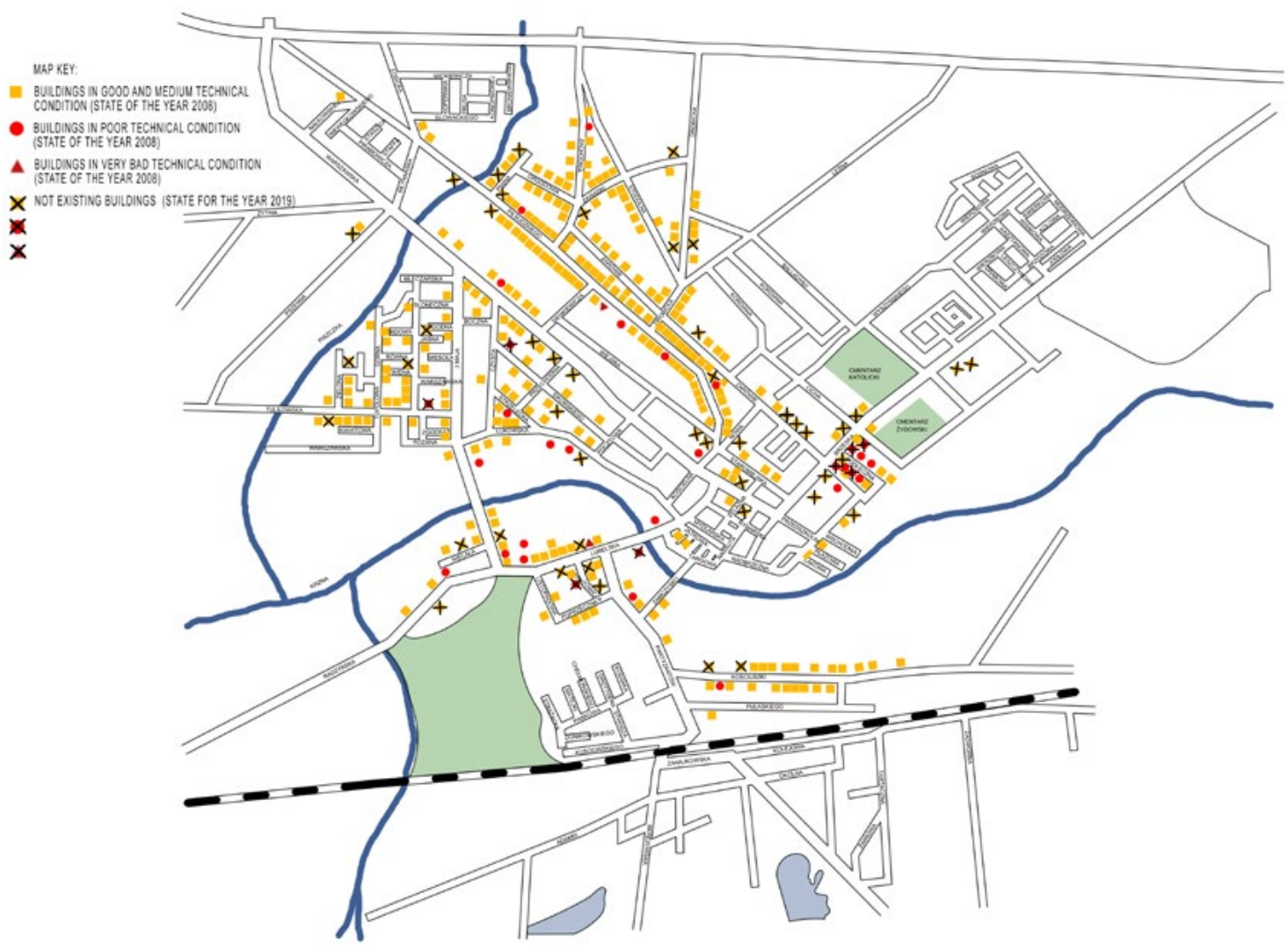

Fig. 3. Plan of the city of Międzyrzec Podlaski with marked buildings. Ed. author based on the BEng Thesis of Tomasz Siedlanowski, titled: Drewniana zabudowa mieszkalna Międzyrzeca Podlaskiego (Wooden residential buildings of Międzyrzec Podlaski), under the guidance of assoc. prof. Eng. Arch. Elżbieta Przesmycka, Lublin University of Technology, Faculty of Civil and Sanitary Engineering, Lublin 2005 and the Master's Thesis by Łukasz Netczuk, entitled Międzyrzec Podlaski - miejsca ożywione (Międzyrzec Podlaski - vivified places), under the supervision of PhD. Eng. Arch. Regina Maga-Jagielnicka, Wrocław University of Technology, Faculty of Architecture, Wrocław 2009 and the author's detailed local vision carried out in August 2019

To illustrate the changes that have occurred in the last decade, a local visit was carried out in 2019. On the plan from 2008, objects were marked according to the state of 2019 together with changes which occurred since the valorisation of 2005 , i.e. objects that have been irretrievably damaged (fig. 3). In their place, contemporary residential buildings or commercial and service facilities were erected. These changes mainly concern the main communication routes, due to the favorable location close to the center. The dynamics of erecting buildings in the interwar period of Międzyrzec was greater than before World War I (table 1). In the years 1918-1933, on newly incorporated areas and as supplement of the city center were erected 194 new wooden houses. In the years 1933-1939 this dynamics was even greater, because in 1939 there was already around 1300 wooden houses and residential outbuildings. The war brought significant damage, thus in 1948, despite three years of reconstruction, timber residential buildings still constituted just over half of the state before the war. Following decades brought changes in city's landscape. As a result of the factors discussed earlier, wooden buildings began gradually to give way to stone ones. In 2005, it is estimated that the number of wooden houses should be around 360. In 1948-2005, the condition of this form of development decreased by almost $44 \%$. Meanwhile, only in 2005-2019 49 objects disappeared (17\% of the previous state). As can be seen from the analysis, wooden housing architecture without systemic protection will soon cease to exist, completely changing the landscape and character of the small town of the Lublin region. The situation is similar in other cities in the region. 
Table 1. Change in the condition of wooden residential buildings in Międzyrzec Podlaski

\begin{tabular}{|ccccccc|}
\hline \multicolumn{5}{c}{ Change in the condition of wooden residential buildings in Międzyrzec Podlaski } \\
\hline Year & $1896^{8}$ & $\begin{array}{c}\text { In years } \\
1918-1933 \\
\text { built }\end{array}$ & $1939^{10}$ & $1948^{11}$ & $2005^{12}$ \\
\hline $\begin{array}{c}\text { Number of } \\
\text { residential houses } \\
\text { (total buildings } \\
\text { amount, including } \\
\text { industrial farm } \\
\text { buildings) }\end{array}$ & wooden & 503 & 194 & ok. 1300 & $638(2083)$ & $\begin{array}{c}86^{*} \\
\text { (ok. 360) }\end{array}$ \\
\hline
\end{tabular}

\section{Legal forms regarding the protection of wooden buildings}

Currently law for protection and conservation provides four forms of monuments protection (Dz.U. nr 162 poz. 1568 z późn. zm. $)^{13}$, as listed: entry in the register of monuments, recognition as a historical monument, creation of a cultural park, establishing protection in the local spatial development plan, as well as an entry in the register of monuments which is not formally regulated ${ }^{14}$. An immovable monument is an object that is a property in itself or is part of a larger complex, created by man or related to his activities. Such monument stands as a testimony of a previous era or important event, thus its conservation is understood as the public interest, due to its unique values, like: historical, artistic or scientific. It is worth noting, that the objects are protected and taken care of regardless of their condition, thus poor technical situation cannot be a premise to question its value and reject the procedure of entry in the monument's register ${ }^{15}$.

Entry in the register of monuments is the elementary form of protection established in Polish legislation. It takes place on the basis of a decision issued by the Provincial Conservator of Monuments (Wojewódzki Konserwator Zabytków - WKZ), which is preceded by detailed archival, field and other relevant research. An entry in the register of immovable monuments is initiated ex officio at the request of the WKZ or the application of a submitter, whom can be: the institution, property owner or is its perpetual usufructuary. In addition, social associations and organizations, whose foundation is to protect cultural heritage (Article $31 \S 2$ and 4 of the Code of Administrative Procedure), also have the right to propose object to the register. After successful completion of the entire procedure, the object is entered in the register of monuments ${ }^{16}$. Unfortunately, described form of protection for wooden houses, built in the interwar period, is neglected. It was noticed, that only a few Cards of Architecture and Building Monuments Records available on behalf of the WKZ, have been created. It was stated, that there are many reasons of monument register unpopularity as a form of these unique objects preservation. One of them is owners insufficient awareness of timber construction value. And the other is society's lack of knowledge about its cultural value.

Another form of protection is a cultural park with special values for a particular region. It is created to protect the unique cultural landscape and preserve the distinctive landscapes with immovable monuments

8 J. Chomicki, Powstanie i rozwój urbanistyczny Międzyrzeca Podlaskiego od średniowiecza do czasów obecnych, Rocznik Międzyrzecki, t. XXXXI-XXII, 1988-1990, s.121.

9 Ibid., p 124.

10 Ibid.

11 J. Chomicki, op. cit, p. 126.

12 T. Siedlanowski, op. cit., p. 47

13 Ustawa z dnia 23 lipca 2003 r. o ochronie zabytków i opiece nad zabytkami (Dz.U. Nr 162, poz. 1568 z późn. zm.), z mocą obowiązującą od dnia 17 listopada $2003 \mathrm{r}$.

14 The issues of monument protection in the commune and voivodship records constitute a separate complex issue that will not be developed in this article due to the lack of recognition of wooden residential buildings with this form of protection in the presented city.

15 https://nid.pl/pl/Dla_wlascicieli_i_zarzadcow/opieka-nad-zabytkami/zabytki-rejestrowe/procedury/ (access 12.07.2019).

16 https://nid.pl/pl/Dla_wlascicieli_i_zarzadcow/opieka-nad-zabytkami/zabytki-rejestrowe/procedury/ (access 12.07.2019). 
characteristic of the local building and settlement tradition (Article 16 (1) of the Act) ${ }^{17}$. Each area covered by this form of protection must have a spatial development plan, which includes conservation protection forms. Currently, it is difficult to separate such an area, in which there is a possibility of preserving a majority of the original urban tissue, containing traditional wooden buildings, because many of these objects no longer exist or they have been repetitively rebuilt, thus losing their unique character. What is more currently surroundings also degraded, among others secondary parcel divisions have been introduced.

Pursuing of historical buildings protection methods, it may be highly useful to contain appropriate information in the study of conditions and directions of spatial development plan for the commune and in local spatial development plan. Such information could relate to use manner, building's nature, maintenance method and possible expansion. The provisions contained in the plans would allow to preserve the unique values of wooden buildings, that were once an element creating a characteristic landscape for a small town.

The form of protection, that has the greatest potential for preserving this buildings's types, is to create a cultural route. It is one of the forms supported by the UNESCO (United Nations Educational, Scientific and Cultural Organization) in the context of cultural heritage ${ }^{18}$.The definition of cultural route was presented by the International Council on Monuments and Sites (ICOMOS), which since 1998 has its own International Committee on Cultural Routes (ICOMOS-CIIC), it assumes that the cultural route is a water, land or mixed trail that has a unique history, showing development humanity, as a multifaceted exchange of goods, ideas, knowledge and cultural values within countries, regions as well as between them, through the long-term mutual interaction of cultures in time and space, which results in a material or immaterial heritage ${ }^{1920}$. In Europe, already in 1985, the resolution of the Assembly of the European Parliament mentions the European Cultural Route, and in 1987 the Program of European Cultural Routes was created and in 1997 the Institute of Cultural Routes in Luxembourg $^{21}$. These institutions promote the the concept of cultural travel in an international context. Howev$\mathrm{er}$, in the case of timber buildings in the Lublin region, more adequate is the definition proposed by L. Puczek and T. Ratz, who present the cultural route, as a thematic and cultural trail, which ethnic value or element of heritage are focus on a given factor, which in itself will be educational and tourist attraction at the same time. They propose a division into routes due to their coverage into: local, regional, national, international ${ }^{22}$. Unfortunately the lack of an unambiguous definition of route categorization, causes difficulties in proper naming of specific enterprises. Armin Mikos v. Rohrscheidt, who introduces the categorization of tourist and sightseeing routes ${ }^{23}$ attempts to order those definitions.

This form of protection would give the possibility of greater protection of wooden buildings in the Lublin region, thus allowing monitoring the changes taking place in the structure of a small town. Another effect should be awareness increase of the local community about the uniqueness of timber heritage. The wooden architecture route of the Lublin region could become a tourist product, attracting not only the inhabitants of the region, but also foreign tourists.

17 https://nid.pl/pl/Dla_wlascicieli_i_zarzadcow/dla-samorzadow/parki-kulturowe/ (access 12.07.2019).

18 UNESCO Annual Report 2005, pp. 34, 83 and 88-89.

19 In the literal wording: "A cultural route is a land, water, mixed or other type of route, which is physically determined and characterized by having its own specific and historic dynamics and functionality; showing interactive movements of people as well as multi-dimensional, continuous and reciprocal exchanges of goods, ideas, knowledge and values within or between countries and regions over significant periods of time; and thereby generating a cross-fertilization of the cultures in space and time, which is reflected both in its tangible and intangible heritage". (ICOMOS CIIC Annual Meeting Report 2003, Attachment 2).

20 CIIC Annual Meeting Report 2003, Attachment 2. Source: http://www.icomos-ciic.org/INDEX_ingl.htm (access: 12.04.2018),

21 Orzechowska-Kowalska K., Zasady tworzenia europejskich szlaków kulturowych, [in] Turyzm, no. 13/2, 2003, pp. 69-78 after: Armin Mikos v. Rohrscheidt, Kulturowe szlaki turystyczne - próba klasyfikacji oraz postulaty w zakresie ich tworzenia i funkcjonowania [in:] Turystyka Kulturowa, www. Turystykakulturowa.org, no. 2/2008.

22 Puczko L., Ratz T., Trailing Goethe, Humbert, and Ulysses; Cultural Routes in Tourism, [in:] G. Richards (ed.), Cultural tourism, Global and Local perspectives, The Haworth Hospitality Press, Nowy Jork, pp. 131-148.

23 Armin Mikos v. Rohrscheidt, Kulturowe szlaki turystyczne - próba klasyfikacji oraz postulaty w zakresie ich tworzenia i funkcjonowania [in:] Turystyka Kulturowa, www. Turystykakulturowa.org, $\mathrm{nr}$ 2/2008. 


\section{Summary}

The number of wooden residential buildings is decreasing every year, being replaced by brick buildings. At many occasions remaining timber households have very little architectural value or are being kept in poor technical condition. In some places, wooden heritage was almost completely erased from the landscape, subsequently built over with catalog houses. This is a huge loss for the cultural scenery, especially in small towns. Wooden buildings were most often located in the suburbs, creating a certain "backdrop" for the city. In addition, localization plots were large and had major gardens. All this provided a unique small-town character ${ }^{24}$.

What is more, those buildings that have survived to this day are subject to significant biological corrosion, which is a consequence of the owners negligence. Another factor destroying this unique timber heritage is poor maintenance and thermal modernization, which is most often carried out in an inappropriate manner and effects in demolition of the unique detail.

It light of aforementioned considerations it can be stated, that appropriate investor training should be carried out, showing how to introduce thermal modernization in such type of constructions properly. It would also be necessary to create a catalogue of characteristic functional-spatial systems and a detail for this region, which could be used to reproduce unique detail. That is why archival and field research are a very important element to deepen knowledge about the construction tradition of interwar period. In addition, it is necessary to carry out a detailed inventory of the preserved objects, in particular the preserved original details and woodwork.

It is worth making every effort to preserve wooden heritage of Lubelszczyzna region in Poland, that is still past years witness and reminds of the difficult time that was after war re-housing of the towns. Especially, that after war damage timber households were preserved and renovated in accordance with all conservation rules. In addition, these buildings represent construction tradition of bygone era, which is now almost completely forgotten. Preservation should be carried out currently and use all possible legal aspects of protection of monuments law. In this case, important step is to enter possible buildings in the register of immovable monuments. Additionally, areas with wooden buildings should be included in the study of conditions and directions of spatial development for the commune, as well as in the local spatial development plan, and both as areas, as well as individual objects should become subjects of conservation care. Such provisions would limit the investors' freedom during renovation works, at the same time preventing secondary divisions of plots.

Yet, the most beneficial solution for both investors and municipalities, would be to create a wooden architecture route of the Lublin region, thus proving the uniqueness of the this area timber development. Propagating this idea would increase tourism in the region and sensitize to the unique buildings of interwar period, becoming a marketing product encouraging to visit these picturesque places.

\section{Bibliography}

[1] Chomicki J., Powstanie i rozwój urbanistyczny Międzyrzeca Podlaskiego od średniowiecza do czasów obecnych, Rocznik Międzyrzecki, t. XX-XXI-XXII, 1988-1990.

[2] CIIC Annual Meeting Report 2003, Attachment 2. source: http://www.icomos-ciic.org/INDEX_ingl.htm (access: 12.04.2018).

[3] Dz.U. $1919 \mathrm{nr} 14$ poz. 176, Dekret w przedmiocie tymczasowych przepisów budowlanych na obszarach byłego zaboru rosyjskiego.

[4] Geresz J., Międzyrzec Podlaski. Dzieje miasta i okolic, 2001.

[5] https://nid.pl/pl/Dla_wlascicieli_i_zarzadcow/dla-samorzadow/parki-kulturowe/ (access 12.07.2019).

[6] https://nid.pl/pl/Dla_wlascicieli_i_zarzadcow/opieka-nad-zabytkami/zabytki-rejestrowe/procedury/(access 12.07.2019).

[7] https://nid.pl/pl/Dla_wlascicieli_i_zarzadcow/opieka-nad-zabytkami/zabytki-rejestrowe/procedury/ (access 12.07.2019).

[8] Majewski J. S., Łuków, district town in the Lubelskie voivodship, Łuków 1930.

[9] Maty Rocznik Statystyczny, r. 4, 1933.

[10] Mikos v. Rohrscheidt A., Kulturowe szlaki turystyczne - próba klasyfikacji oraz postulaty w zakresie ich tworzenia i funkcjonowania [in:] Turystyka Kulturowa, www. Turystykakulturowa.org, nr 2/2008. 
[11] Netczuk Ł., master's thesis entitled Międzyrzec Podlaski-miejsca ożywione, (Międzyrzec Podlaski - vivified places), under the supervision of PhD Eng. Arch. Regina Maga-Jagielnicka, Wrocław University of Technology, Faculty of Architecture, Wrocław 2009.

[12] Orzechowska-Kowalska K., Zasady tworzenia europejskich szlaków kulturowych, [in] Turyzm, no. 13/2, 2003, pp. 69-78 after: Armin Mikos v. Rohrscheidt, Kulturowe szlaki turystyczne - próba klasyfikacji oraz postulaty w zakresie ich tworzenia i funkcjonowania [in:] Turystyka Kulturowa, www. Turystykakulturowa.org, no. 2/2008.

[13] Przesmycka E., Pol E., Architektura okresu międzywojennego w kreowaniu tożsamości na przykładzie regionu lubelskiego, [in:] Zeszyty Naukowe Politechniki Poznańskiej. Architektura i Urbanistyka, z. 30, 2014, pp. 223-231.

[14] Puczko L., Ratz T., Trailing Goethe, Humbert, and Ulysses; Cultural Routes in Tourism, [in:] G. Richards (ed.), Cultural tourism, Global and Local perspectives, The Haworth Hospitality Press, Nowy Jork.

[15] Siedlanowski T., BEng Thesis titled: Drewniana zabudowa mieszkalna Międzyrzeca Podlaskiego (Wooden residential buildings of Międzyrzec Podlaski), under the guidance of assoc. prof. Eng. Arch. Elżbieta Przesmycka, Lublin University of Technology, Faculty of Civil and Sanitary Engineering, Lublin 2005.

[16] Tłoczek I., Polskie budownictwo drewniane, Wrocław 1980.

[17] UNESCO 2005, Annual Report.

[18] Ustawa Budowlana. O prawie budowlanym i zabudowaniu osiedli z dnia 16 lutego 1928 roku, Warszawa 1928.

[19] Ustawa z dnia 23 lipca 2003 r. o ochronie zabytków i opiece nad zabytkami (Dz.U. Nr 162, poz. 1568 z późn. zm.), z mocą obowiązującą od dnia 17 listopada 2003 r.

[20] Ustawy i rozporządzenia z dziedziny budownictwa obowiązujące w Państwie Polskiem: ustawy i rozporządzenia wydane przez władze polskie do dnia 1 czerwca 1923 r. obowiązujące bądź na obszarze całego państwa, bądź w poszczególnych dzielnicach oraz przepisy wydane przez b. władze rosyjskie i okupacyjne niemieckie, obowiązujące na obszarze b. zaboru rosyjskiego, ed. by Gustaw Szymkiewicz, Warszawa 1923. 